\title{
A CHILD-FRIENDLY CITY: A YOUTH CREATIVE VISION OF RECLAIMING INTERSTITIAL SPACES IN EL MINA (TRIPOLI, LEBANON)
}

\author{
Nabil MOHAREB ${ }^{1^{*}}$, Eslam ELSAMAHY ${ }^{2}$, Mary FELIX $^{3}$ \\ 1, 2, ${ }^{3}$ Beirut Arab University, Faculty of Architecture, Design and Built Environment \\ P. O. Box 11-5020 Riad El Solh, 11072809, Beirut, Lebanon
}

Received 20 October 2018; accepted 20 April 2019

\begin{abstract}
Although old Arab cities were designed bottom-up to follow the needs of their users, public spaces for use by children were not fully considered. This paper is an outcome of a funded project that hosted 30 youth (aged 13-17 years old) from different parts of El Mina city, located in the North of Lebanon, Tripoli. The project's aim was not limited to capacity building or designing a framework for youth participation as a vision for a child-friendly city alone, as it also demonstrated community participation with the youth to realize a design vision in an unused interstitial space by the youth in the ancient city of El Mina. The funded project consisted of many different stages; this paper focuses on the site selection, design process and the final stage of implementation. The results highlight the lessons learned from the youth's participation, the adaptive reuse of interstitial spaces, in addition to the various interests of the project's stakeholders.
\end{abstract}

Keywords: child-friendly city, creative learning, El Mina (Tripoli), interstitial spaces, youth participation, youth vision.

\section{Introduction: the project background and related literature review}

The concept of youth/child participation in decision-making regarding the urban form of their city is useful for both the youth as well as for the community. Participation as a principle is important for a child's mental and psychological development, better outcomes and social inclusion, and good governance (Stein, 2014).

The aim of the funded project, Our City - Our Way, was to empower thirty young people from El-Mina city located in the North of Lebanon. The capacity-building provided by the project prepared the youth to advocate for an active citizenship role to be recognized by the local authorities, through a series of workshops and cultural training processes, that led them proactively to understand the key urban functions and accordingly design and implement their model of a creative child-friendly city (CFC). The idea was originated by the El Safadi Cultural Center - Centre Culturel El Sfadi, who teamed up with Beirut Arab University (BAU) as an

*Corresponding author. E-mails: n.mohareb@bau.edu.lb; n.mohareb@yahoo.co.uk 
educational facility, and the local authority of El Mina Municipality. It was a one-year project that started in February 2017 and ended in February 2018. The main idea emerged from local needs: training the youth to be proactive in their environment and to share their feeling, ideas and needs with civil society, and engaging the community to reclaim interstitial spaces (ISs) in El Mina city that have great potential but are not currently being used to the full.

Tripoli, Lebanon is the second largest city after the capital, located on the North coast of Lebanon, $85 \mathrm{~km}$ by road from Beirut. In 1289, Bahri Mamluk sultan Al-Mansur Qalawun abandoned the old city on the harbour, which is currently known as El Mina (the Arabic word for "harbor") (Bosworth, 2007). He built a new city on the Pilgrims' Hill about three kilometres inland, which was the origin of the present old city. From the 14th to the end of the 19th centuries, Tripoli consisted of what are now the old parts of El Mina and the old city. For a long period of the city's history, it was attached to Damascus; however, the British conquered the region in 1918, and Tripoli became part of Lebanon in 1920 (Gulick, 1963). During the civil war from 1975 to 1990, the city witnessed further population movements and displacements that changed the demographic profile of the city. The civil war was also responsible for stopping the oil refinery and the railway network. This further segregated both physically and economically the city from its hinterlands as well as from Beirut, which contributed toward raising the poverty levels within the city. Additionally, this led to an increase in illegal construction and the development of poor enclaves in the city due to the deteriorating economic conditions. The comprehensive population count for Tripoli's urban area has grown to 508 990. The cadastral area of El Mina is around $3.82 \mathrm{~km}^{2}$, with an estimated density of 20459 persons $/ \mathrm{km}^{2}$ (Un-Habitat, 2016). Currently, the city suffers from a lack of creative vision regarding development to use its current potential. Although it possesses all of the necessary unused infrastructure, such as the railway terminal (not functioning), huge Olympic stadium (not working) and huge International Fair of Rashid Karami (partially functioning on minor occasions).

ISs, by definition, are spaces that are small or of an irregular shape. They are ill-defined sites, with tricky ownership rights or abandoned areas, inaccessible, obsolete or unproductive spaces and buildings, leading to sites being overlooked or ignored, contributing to this idea of a time gap and opportunist chances for transgression (Shaw \& Hudson, 2009; Lau, 2012). Henri Lefebvre used the term "micro public space" which suggests the possibility of public-ness and urbanity in even the smallest urban spaces (Lefebvre, 1991). As ISs are the counterpart of the known and formally inhabited parts of cities, they exist in contrast and at times in resistance to these and, due to their indeterminacy of programs and ownership, are often neglected (Lau, 2012).

These spaces represent an opportunity for the youth to reclaim them. As a result of the "adultization" of childhood, where children's time is filled with organized activities such as sports, music and scheduled activities, much of their unstructured time is spent at home or school in front of computers. Playgrounds have become more ordinary and less challenging. Rarely do children use playgrounds without adult supervision today (Francis \& Lorenzo, 2002). Since the old Arab cities were less designed to include the needs of youths or children in its open spaces, ISs might be the only available solution to accommodate those needs without demolishing one activity for the sake of another. 
The funded project consisted of many stages, starting from the preparation stage, the criteria for selecting the youth from El Mina city, setting the capacity building training methods for the youth, the different stages of engaging with the local authority and community, understanding El Mina city and assessing its potential development, conveying the youth's creative vision for their city in general and for the usage of open spaces in particular, selecting the experimental site, designing the project and, finally, overseeing the implementation process. This paper aims to address the youth vision of reclaiming ISs and focuses on selected stages from the funded project, such as: the site selection, design process and the final stage of implementation. In addition, it provides an overview of the other related stages. Finally, the paper discusses the lessons learned from these stages and from the interaction with different local stakeholders.

\section{Child friendly projects as a creative approach}

The UNICEF National Committees and Country Offices (2009) define the term "CFCs" as follows:

"A child friendly city is the embodiment of the convention on the rights of the child at the local level, which in practice means that children's rights are reflected in policies, laws, programmes and budgets. In a child friendly city, children are active agents; their voices and opinions are taken into consideration and influence decision making processes".

In 1996, the Second United Nations Conference on Human Settlements launched the official Child Friendly Cities Initiative UNICEF, with the aim of making cities worldwide more liveable for children (Chan, Erlings, Mizunoya, \& Zaw, 2016). CFC is different to the though extensively researched - concept of urban design and environment that is equally referred to as "CFCs", that seeks to design cities with the needs of children in mind (with or without their involvement) (Chan et al., 2016). The latter concept is sometimes categorized as an "environmental perspective" (Hassan M. Nour, 2013). The seven realms approach summarizes the suggestion of children's participation in city design and planning as follows (Francis \& Lorenzo, 2002):

a. Romantic approach "Children as Planners": children define and make their own future, often without adult involvement.

b. Advocacy approach: planning "for" children with needs advocated by adult planners.

c. Needs approach: research-based approach that addresses children's needs.

d. Learning approach: participation through environmental education and learning.

e. Rights approach: the theory that children have rights that need to be protected.

f. Institutionalization approach: planning "by" children but within institutional boundaries set by the adults, authorities, and clients.

g. Proactive approach: children are active participants in the process but designers/planners play an important role.

Meanwhile, the former idea was more about legalizing the idea of CFC in the city's vision, based on UNICEF Office of Research-Innocenti, which identified nine building blocks that are central to the process of incorporating the CFC framework and thus making cities 
and communities child-friendly (Chan et al., 2016). The nine building blocks are as follows (International Child Friendly Cities Secretariat, 2018):

a. Children's participation: active involvement in the decision-making process.

b. A child friendly legal framework: ensuring legislation to protect the rights of all children.

c. A city-wide children's rights strategy: comprehensive strategy for an agenda based on convention.

d. A children's rights unit or coordination mechanism: ensuring priority consideration of children's perspective in the local government structure.

e. Child impact assessment and evaluation: a systematic process for assessing the impact of any decisions on children.

f. A children's budget: ensuring an adequate budget for children's development.

g. A regular state of the city's children report.

h. Making children's rights known.

i. Independent advocacy for children.

Child participation involves recognizing the capacity of children to express their views and influence the decisions that affect their lives and the community in which they live. Roger Hart's ladder of participation consists of eight rungs: manipulation; decoration; tokenism; assigned but informed; consulted and informed; adult initiated, shared decisions with children; child initiated and directed; child initiated, shared decisions with adults (Chan et al., 2016; Hart, 1992; Stein, 2014). Hart's model has been criticized for being too hierarchical in nature and for failing, at times, to accommodate different settings (Stein, 2014), so it should be seen, not as rungs, but as equally important levels of participation, apart from the first three points.

From international examples, Kazakhstan CFCs (Malone, 2013) focuses on designing an accreditation model that is consistent with international best practice and provides recommendations and an implementation strategy for CFC in Kazakhstan. Their approach was based on a number of workshops to formulate that model and interviewing children, youth, service providers and parents about the city's friendliness to a child. Another example that integrates young people's ideas when redesigning open space is Colorado (Derr et al., 2013). The process involves the redesign of parks and civic areas and the identification of issues for city planning in support of children's rights to engage in active citizenship from a young age. Each action group was implemented differently. The youth articulated their ideas using pictures and then these converted to a single banner. High school students developed an interview protocol to determine whether or not downtown businesses hired minors and if they had any special rules for youth in their establishments, while the high school students administered and analyzed the results of a survey of existing and desired nightlife opportunities.

In Lebanon, there were two previous known CFC projects, they were mainly based in Saida city. The first was in 1999 with the title "Growing Up in Saida" (Chan et al., 2016), and the second in 2017 (Masri, 2018). The later project aims to develop a youth participatory tool to engage the children of Saida in the urban planning process and decision-making through conducting a pilot workshop. 
Since the concept of legalizing CFC is less familiar in Middle Eastern cities in general, and almost unknown in Tripoli in particular, the later concept of legalizing CFC was not the target of this project. It is an attempt to provide a practical demonstration that shows the community and decision-makers that it is possible to consider the needs of the youth within their own city using a small amount of funds and minimum requirements to adjust or add new laws. This project instead attempts to instigate the idea of CFC in the community and the administrative authority through encouraging the youth to share their vision with other stakeholders. It is aligned with the first block "Children's Participation" in the nine blocks discussed above. As it represents the most fundamental step - fostering children's participation - it cuts across the entire process. It represents both a building block in itself and a process influencing each of the other steps (Hassan M. Nour, 2013). It also considers three out of the seven realms: the romantic, learning and proactive approaches.

It is clear from the previous literature that the youth participation in CFC projects tends to be limited to the first four levels in Hart's ladder, while this project focuses more on the other, higher levels of participation, that include: consulted and informed; adult-initiated, shared decisions with children; and child-initiated and directed (Chan et al., 2016).

This project extends its focus to the realization level; it is not limited to the capacity building training of youth nor does it seek to set up polices or frameworks without testing them. The project moves beyond this to provide the youth with the means and tools to produce an idea, visualize it, meet with different stakeholders (starting with the decision-maker and ending with the local residents) to promote and present their creative vision and finally construct their thoughts on a real site. This experiment was beneficial not only to the youth but also to all participant stakeholders, who are the selected youth participants in this project, the municipality of El Mina, El Safadi Cultural Center - Centre Culturel El Sfadi, the Faculty of Architecture - Design \& Built Environment on Tripoli Campus, representing BAU and the local residents, including the children.

\section{Education method used for capacity building}

The capacity building techniques used in this project were based on a series of 15 workshops, site visits (more than five group site visits) and construction workshops (to create the street furniture facilities). All of these series were governed by the learning dimensions' method, from the zero dimension (0D) to the seventh dimension (7D) (Barrow \& Mathew, 2005). Although this method was not intended to be used by the youth in its original usage, however, it includes all of the skills needed for youth capacity building. The method starts by creative thinking about ideas as a $0 \mathrm{D}$ level, which starts with how to generate visions, and write them down as a $1 \mathrm{D}$ process. A $2 \mathrm{D}$ (two dimensional) skill is needed, such as drawing, photography and basic cartography, while a 3D (three dimensional) skill is used for modelling, and by adding time, the idea moves to another dimension, which is the $4 \mathrm{D}$ (four dimensional) level, which encompasses various methods of presentation. This is followed by $5 \mathrm{D}$ (five dimensional), through simulation techniques from learning basic augmented reality and analytical skills, and then 6D (six dimensional), through the fabrication skills necessary to build the physical models. Finally, 7D is the realization of these ideas in reality at the selected site. 


\section{Youth creative vision: problems and constrains}

In order to select the required 30 youths for the project, a call out for participation was made to all interested youth (aged from 13 to 17 years old) in El Mina city at BAU. An image-based survey was designed to understand the youth's initial vision for their city and how they see it (see Figure 1). This understanding will provide the foundation for understanding their current knowledge and engaging them properly in the capacity building training. The response rate to the questionnaire was 108 out of 114 youth, representing $94.7 \%$ who completed the survey (54.39\% male and $45.61 \%$ female), from 20 different educational bodies and scouting organizations in El Mina city.

Although the youth stated that their city is suffering from severe neglect and a lack of development projects besides the huge problems related to electricity and garbage, still $71.7 \%$ responded positively when asked "Do you think your city 'El Mina' is a beautiful place?". This response percentage is important as it gives a clue to the youth's positive vision of their city, that might increase their willingness to participate in the program for making their city a better place. The youth were also asked how active they are after school and at weekends. The result showed that $52.3 \%$ were active after school through, participating in either cultural or sport activities, while thus percentage increased to $85.2 \%$ at the weekends. This percentage indicates that the youth are active and might benefit from reclaiming the ISs in El Mina in order to access more beneficial activities.

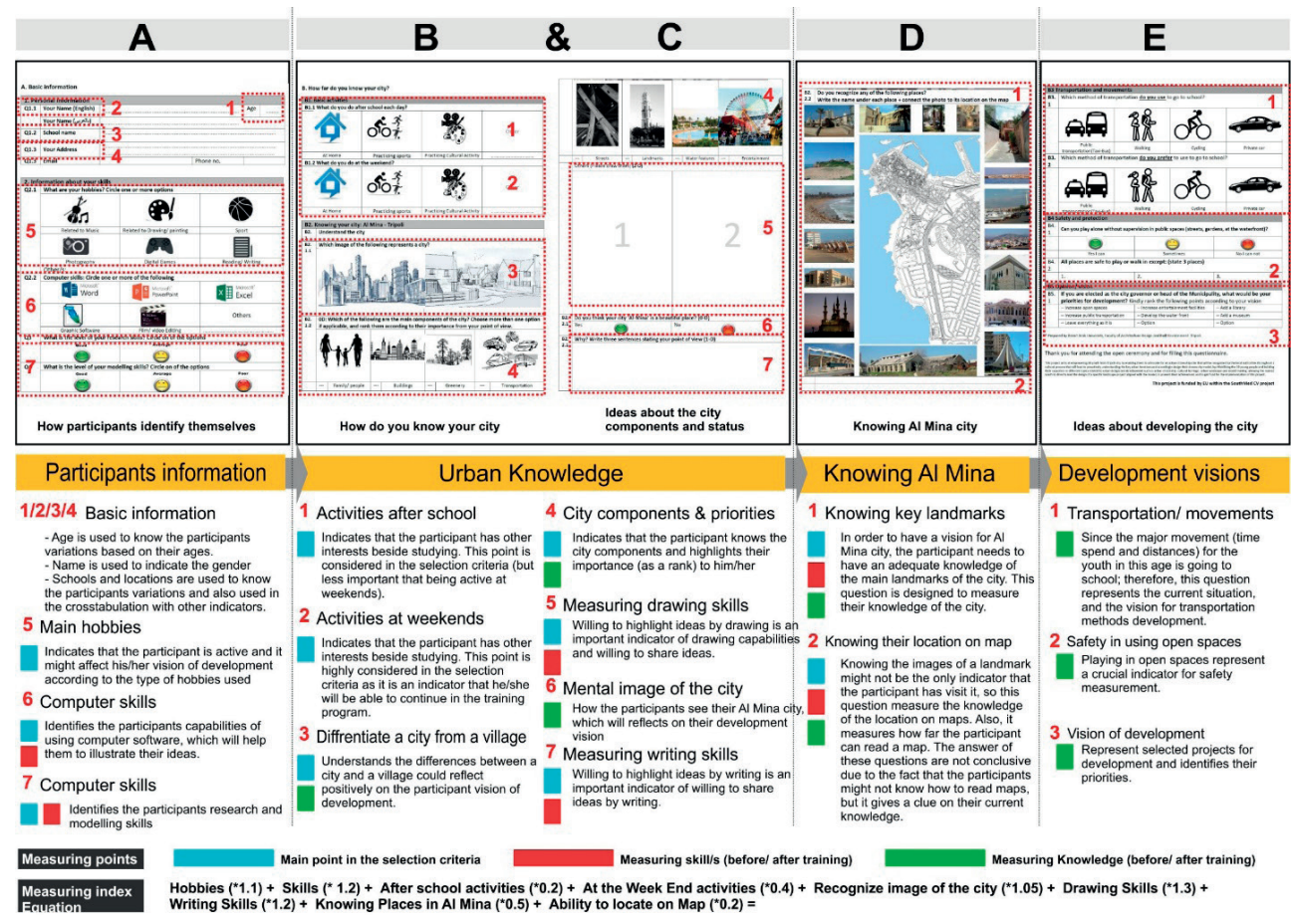

Figure 1. The image-based questionnaire for the initial kick-off event at Beirut Arab University for selecting the participant youth (source: created by authors) 
In order to establish their initial vision about what are the most import development targets that their city might need, the questionnaire gathered their most import points and ranked them according to their responses (see Figure 2). The youth chose open spaces development as the most important issue, followed by increasing the public transportation and developing the city's waterfront. Their least important action was to leave everything as it is. This results highlights that the youth are willing to be proactive in their community and have set open spaces as their priority for development.

Since the city is facing an electricity problem as the electricity provided by the official grid covers an almost-intermittent 12 hours, while private generators fill the necessary needs and gaps throughout the day. This issue led to a poorly light streets at night. Other problems such as some previous conflicts, such as the civil tension and currently the increasing number of Syrian refugees, there was concern about the youth's feelings of security and safety and whether they are able to use and play in outdoor spaces without supervision. The majority of both genders and all ages feel that it is safe, totally or sometimes, to play outdoors without supervision by older people, even among the younger youth (see Figure 3).

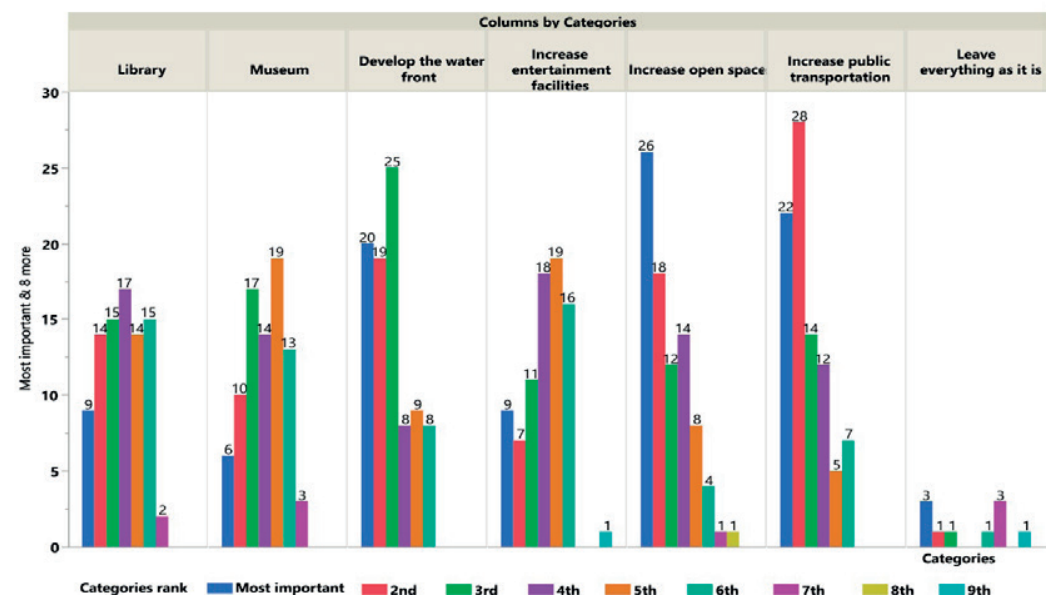

Figure 2. The youth's ranking of the required projects in their city, El Mina city (source: created by authors)
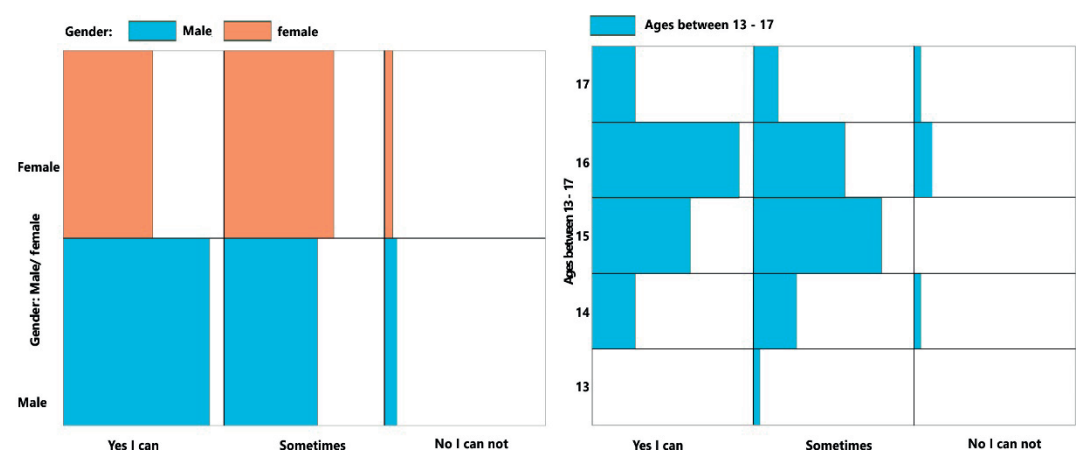

Figure 3. The youth's ability to play outdoors without supervision by older people, categorised by gender (left), the same question but the results are categorized by age (right) (source: created by authors) 
The outcome of the previous three questions clearly indicate the background of most of the current youth of El Mina and how they feel about their city and the most important development targets within their vision. They are active, have chosen open spaces as a priority for development, and do not feel afraid to use them.

The previous section was important as it showed why the youth's vision focused on reclaiming open spaces in El Mina city, Tripoli. The next sections focus on the last three stages of the funded project: site selection, development of the design idea and the implementation phases.

\section{Criteria for selection between the three sites}

The capacity building training at this stage was focused on where and how to select an appropriate site for implementing the youth's creative design. In the photography workshop session, the youth were invited to take photos in the old sector of El Mina to discover more places and locate the best sites for implementing their vision. Although all of the participants are living in El Mina or on its periphery, still some places are unfamiliar or unknown to them. In order to implement the youth's ideas, they selected three different locations in El Mina city after the photography session and environmental investigation (see Figure 4). A brainstorm meeting was held with the three partners to establish the criteria for the site selection in addition to highlighting the available budget for implementation. Eight points were chosen by the youth from the general SWOT analysis (strengths, weaknesses, opportunities and threats) that was held in an earlier workshop to understand the potential of El Mina city in general. The following eight points were used to select one of the three chosen sites (see Figure 5):

a. Plaza: the site should have an extra appropriate size to accommodate activities beside the street movement corridor.

b. Accessible: the place should have high pedestrian accessibility and low vehicle traffic.

c. Limited commercial spaces: to avoid annoying the owners of commercial entities.

d. Not crowded: to add a new activity to the space and not be crowded due to other activities.

e. Potential to grow: to add more future activities.

f. Limited number of residential buildings' entrances: to minimize annoying the residents.

g. Plot area within the designated budget: the selected project size should fit the budget.

h. Not surrounded by high buildings: to minimize the noise, and increase the sun exposure.

Through a voting system that involved all of the participants, that was based on inviting the participants to rank the three sites using an eight point-system on the questionnaire, the youth selected site number two (see Figure 4). It seems that the three sites had higher values for points $(\mathrm{H})$ and $(\mathrm{G})$ but received lower scores for points $(\mathrm{E})$ and $(\mathrm{F})$.

The site is located at Kifah Street behind Khan el-Tamasely in El Mina city (Khan in Arabic means a place where visitors were staying with their animals: the ground floor of the animals and the upper was reserved for guests). It is a very small public space, which has a few openings, 

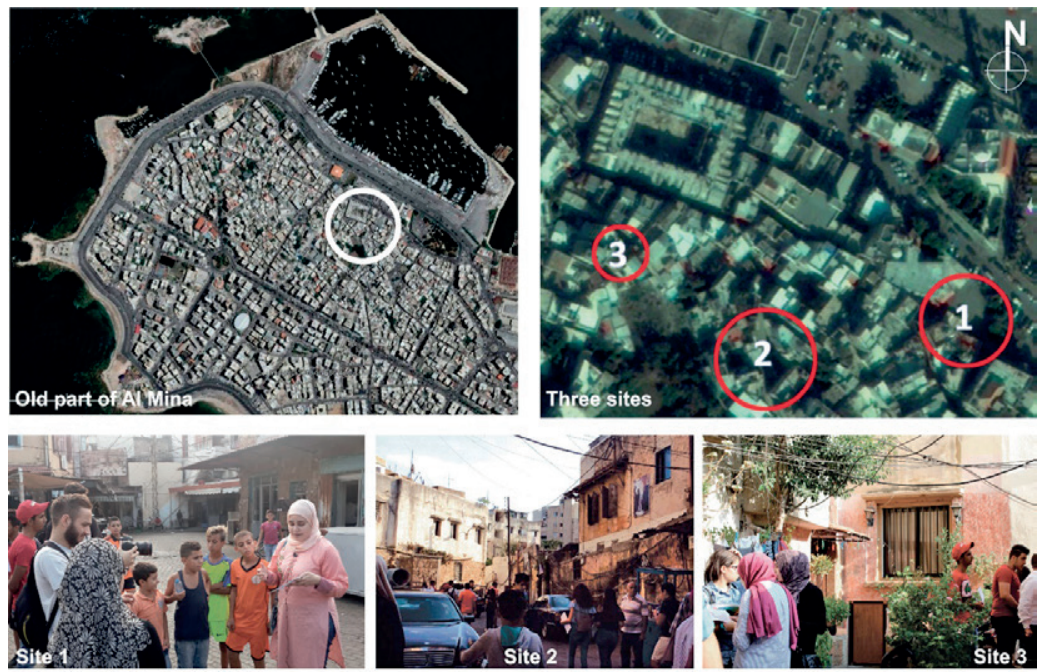

Figure 4. The three potential locations of the site for implementing the youth's design idea (source: created by authors)

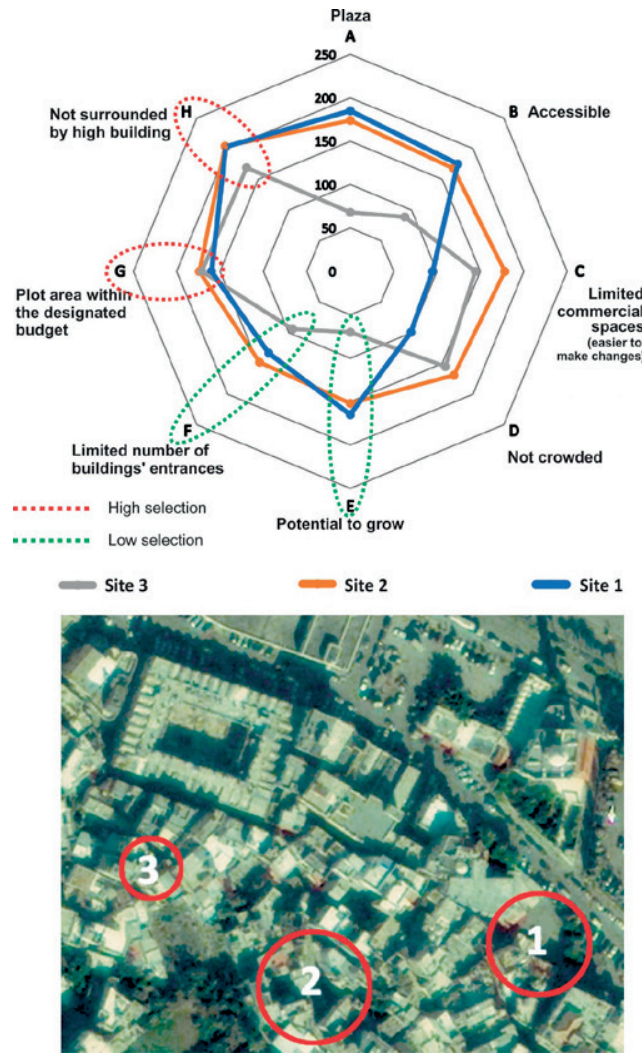

Figure 5. The criteria for selecting the project site from three proposed locations (source: created by authors) 
passive facades and no commercial activities (see Figure 4). The space is occasionally used as parking for four cars. The main landmark is an old "Sabil" (the Arabic name for a free public drinking-water facility), which is currently not functioning. The space is small enough to fit within the given budget, and is completely neglected and not used properly, which means that the site has positive potential for implementing the participants' creative ideas.

\section{Youth creative vision: design phase}

Based on the capacity-building and the learning skills of the previous stages, the youths were gathered in groups of three to six to develop their design ideas using physical models with simple materials (see Figure 6). The youths were encouraged to design their own street furniture and define applicable activities within the given space in their proposed design. After various trials, the outcome was six different alternatives. Further discussions followed to identify the advantage of each proposed model and how it might fit within the surrounding context and the allocated budget, which is 10000 United States dollars. Voting was held to select the most appropriate ideas from each activity in order to create the final collective proposal based on the shared and approved ideas. Further sessions were devoted to developing the design idea based on further discussions and a SWOT analysis was applied to select the most appropriate design. The selected idea was based on two different zones: the kids' zone, and seating zone, that could be used for reading or developed further to accommodate monthly cultural activities (see Figure 7).
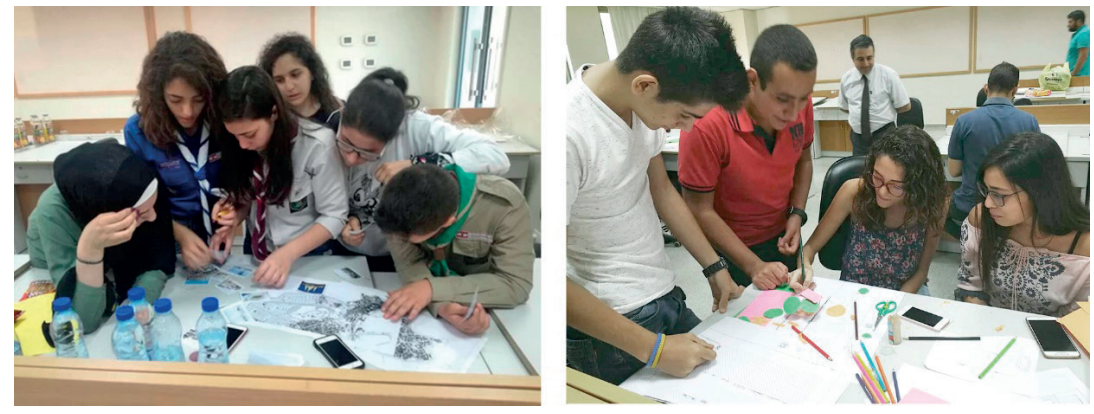

Figure 6. The design phase based on number of tailored workshops (source: created by authors)
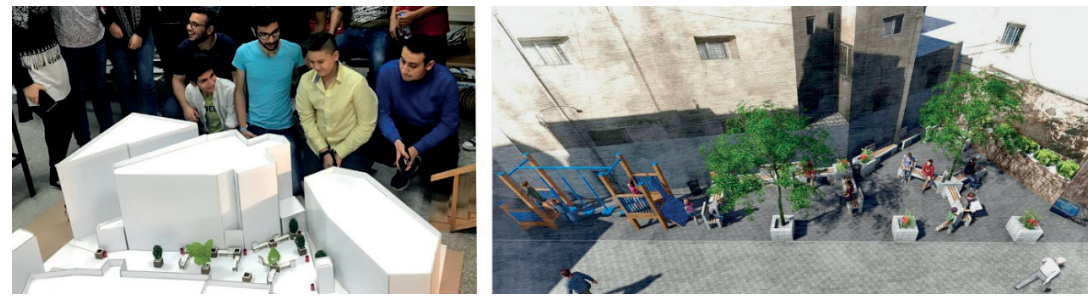

Figure 7. The final physical model of the selected idea (left) shows the sketch-up 3D model for the site (right) (source: created by authors) 
The design increases the amount of greenery, and introduces new activities with appropriate street furniture that fits both the children and youth's needs without affecting the current pedestrian accessibility level of the area (see Figure 7). The design also respects the current openings and activities of the area, without making any changes. Beatification interventions were needed for the surrounding facades and the electricity wires, that were haphazardly scattered across the residential facades, needed to be rearranged. This point became clear from the number of site visits to the project location. At this stage, the youth had a solid idea but still did not know how it would impact on the local residents when discussing it with them.

\section{1. Meeting with the public}

Meeting the local public community is a very important stage when presenting a project idea, to gain their support. It is a step that changed the youth's vision from an idea into a real solid project that might be altered according to their ability to convince the locals. The preparation phase for this step involved meeting the project partners in order to brainstorm an appropriate approach for discussing the design with the local community. In order to fulfil this target, a series of training sessions for the youth was designed to enable them to present their ideas as a group or individuals. A public hearing was held in El Mina, at the project location, and a number of residents, in addition to the local administration from the municipality, attended the event. The youth were involved heavily in the event, explaining, discussing and responding to any questions or clarifications needed by the public. At this point, it seemed that this was the first time that the main stakeholders were gathered to discuss a project that concerns the locals. The stakeholders at this meeting are the local youth with their vision, the local residents with huge expectations, the municipality as a local authority, the academic institute which is the BAU, and finally the local children (see Figure 8). The older residents took advantage of the existence of the municipality and, at the end of the meeting, expressed their needs, which involved complaining about the physical condition of their houses, especially the roofs.
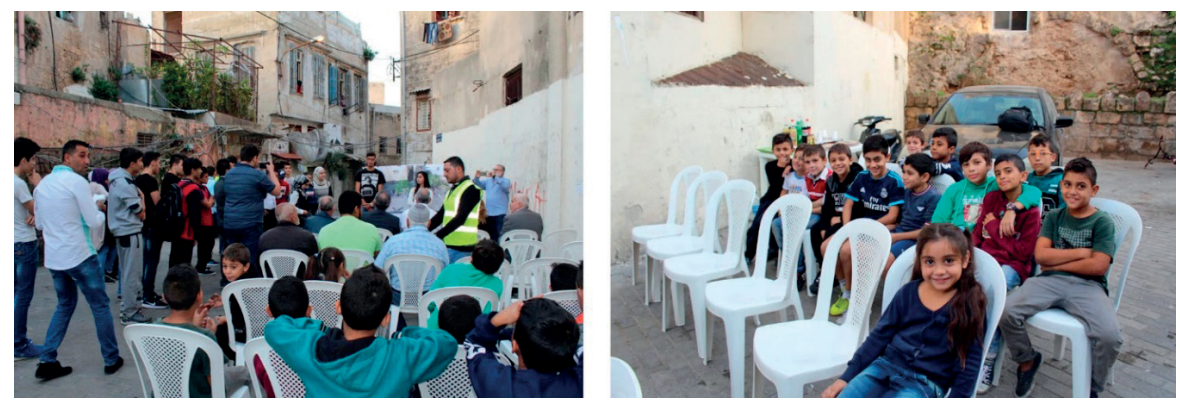

Figure 8. The youth's presentation to the local community at the selected site (left), another photo shows the local children who were curious to see what was happening at the site (right)

(source: created by authors) 


\section{Implementation phase}

This was the most dynamic and difficult phase of the project. It was divided into three stages: building, preparation and finalizing. This phase makes this project unique. It not only increased the youth's capacity building through a series of theoretical or hypothetical training but also moves to implement a genuine creative vision that is transformed into a real project and needs to be constructed within a defined time with limited resources. The first stage was to construct in-house benches with flower boxes to be used at the project site. Since the participating youths have designed the street furniture but did not have the necessary construction skills, as more time would have been needed to develop these skills, a joint venture project with third year BAU undergraduate students was organized, in order to construct the final benches within their execution design III course, based on the design and supervision of the youth (see Figure 9). This meant that the participating youth were also exposed to design and construction techniques, and this method is called design-build (Mohareb \& Maassarani, 2018), which involves designing a product and building it with real scale and materials. The second stage was on-site, and involved preparing the open space with the minimum of beautification interventions to the surrounding buildings, as well as repairing some damaged flooring tiles. El Mina municipality was responsible for this stage. The third stage was placing the street furniture in its designated place and finalizing the project. All of the participants helped to finalize the project on time.

Within the third stage, when preparing the site, by-passing locals appreciating the existence of a seating area, as this facility does not exist in their open public spaces in El Mina. They used the benches, although they were not located in their final place yet, as a resting point before moving on to their destination (see Figure 10).

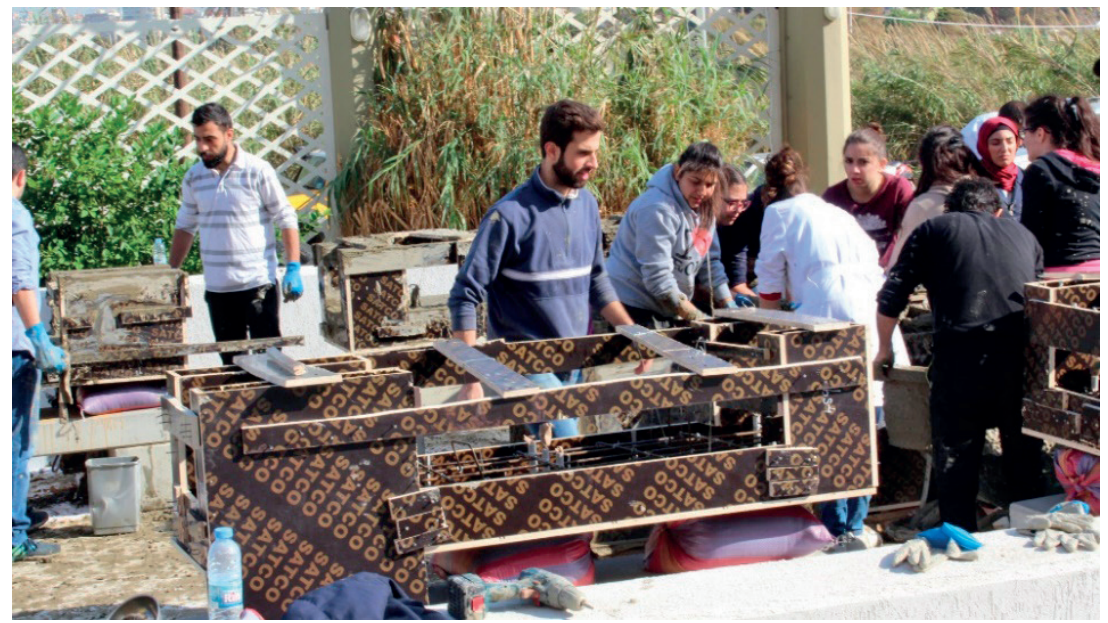

Figure 9. The construction phase of the street furniture: seating benches and flower boxes. It was constructed in-house on Beirut Arab University Tripoli campus with the help of Beirut Arab University level three architecture students (source: created by authors) 

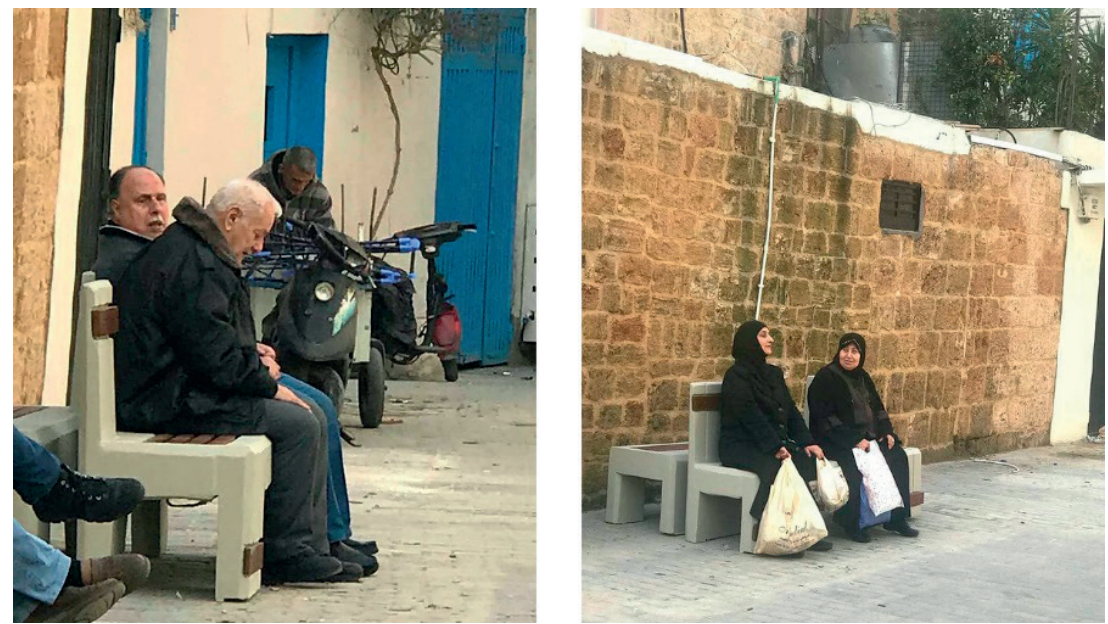

Figure 10. The older people's usage of the street furniture (seating benches) during the construction phase. The benches were not yet located in their final places (source: created by authors)

\section{1. Finalizing the project}

The project was finalized in March 2018, one year after the funded project started (see Figure 11) to differentiate between the before and after intervention (for more details see Figure 12). The real time required for the construction and beatification process was about three months after the youth created their design. On the opening day, everyone participated, especially the children of the neighbourhood. They did not leave the provided playing facility for a second. The youth were very proud of their accomplishment, as they had given life to unused space, their design had been implemented and they were standing in the middle of it.

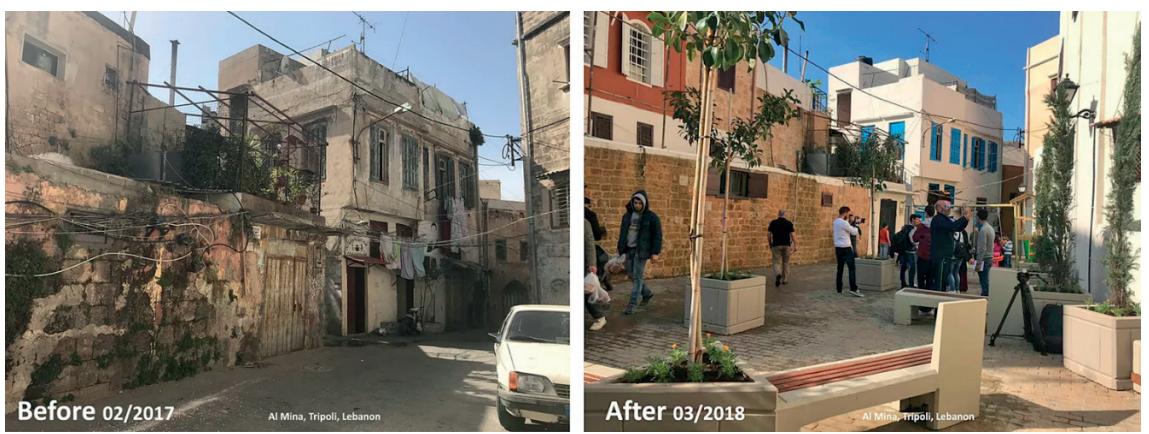

Figure 11. The site prior to intervention on February 2017 (left) and the site after completion in March 2018 (right) (source: created by authors) 

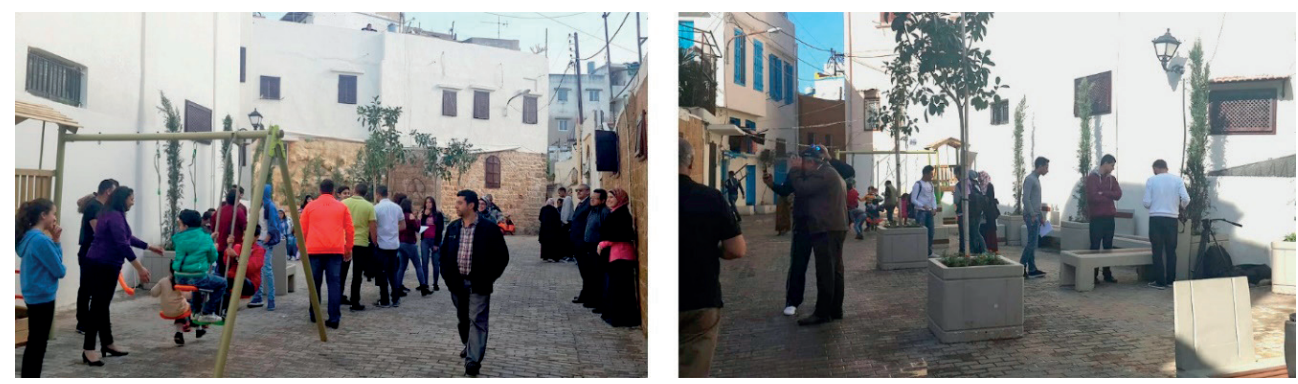

Figure 12. The children's game that was installed in site (left) and the street furniture installed at the site (right) (source: created by authors)

\section{Learned lessons and discussions}

Historical spaces in old cities in general and in El Mina in particular offer more opportunities to include activities for youth, despite the fact that these spaces are not planned to host such activities. In this experiment with the youth and local children, we witnessed the eagerness to play among the neighbourhood children, in any sort of playing space, even with the minimum facilities provided, such as the outdoor game facility that the project installed. Four main lessons were learned from this experience concerning different stakeholders' reactions to the project's outcome and process.

The first lesson was the children. They will adapt and use any space to play in. Currently, they are using spaces for running, playing hide-and-seek, and playing football whenever possible, and "possible" here mains whenever their elders allow it, due to the high level of noise that this generates, according to one of the locals interviewed. In addition, there are no places devoted to act as a playground continuously for children. While installing the play facility in the project space, children gathered from the entire neighbourhood, eager to play and even unable to wait until it was completely installed. They kept asking, "Is it ours?", "Can we play in it?". Moreover, after its installation, they were thrilled to continue playing there. The local children did not care very much about the other project tasks of restoring and enhancing the building facades, nor were they interested in the street vegetation. Their focus was solely on using the play facility, and how to use the available space as a new play zone.

The second lesson was the youth's vision. When discussing the youth's vision for this project, they were fully aware of the problems and opportunities that this space might provide. Their awareness arose from their experience as the main users of such places in El Mina. The youth's vision was balanced between what the adult and child users might need from such small spaces. The youth's main complaint was that they felt that spaces in the historical part of El Mina were designed for grownups, while completely ignoring the children and youth's needs. They were eager to benefit their city.

The third lesson was from the locals. They were very grateful that their place received the project's attention to implement the youth's vision. Although they encouraged the youth during the public hearing, the locals wanted to steer the main concern to their own old buildings' physical condition. They asked whether the project might deviate its focus to maintaining the 
buildings rather than concentrating on unused space, according to their priority. Although local support is essential for any applied project and it was critical to hear their needs, the problem was that their needs were focused only on their own buildings out of self-interest rather than on shared spaces. They supported the street furniture, landscaping, and restoration of the buildings' façades, but did not fully support the use of this space as a regular play facility, as they currently used it to park their cars, even though it is difficult to manoeuvre cars into the space, due to the spatial configuration of the old streets.

The fourth lesson was from the local authorities. When the draft proposal was discussed with the local authorities, they seemed to be aware of the attitudes of the locals of different ages. The discussion turned into an on ground experience verses a visionary proposal by the youth. The local authority focused on the renovation and restoration of the façades and the lighting features, while expressing doubts about the success of the play facility and whether it should be installed at all, as it should be heavy duty. This focus was different from the youth's vision, as discussed above. The discussion was useful for all sides, when the local reactions were added to the project when it was discussed openly with the public at the site. We think that this was the first time that the three groups of stakeholders heard about the needs of each other. However, the day after the project's opening ceremony, it came to our knowledge that the local authorities had removed the play facility because children from the project's location and the adjacent ones were fighting over who should play in and use the space. This swift action by the municipality might solve the current struggle between the children, but does not sustain as a long-term solution to the need for a play space and facilities for children and youth. Instead of removing the play facility, the project team suggests reclaiming ISs to plan more playgrounds in different places, to ensure that every child has a nearby play space or facilities.

Public participation and support are crucial for the success of any project involving the adaptive reuse of IS. The term "public" means the local users of different ages, local authorities and the local media. This project was successful in building the capacity of the youth and this success was measured quantitatively and qualitatively through different entry and exit questionnaires. The youth has learned how to express their ideas and vision for their city using different methods in private and public presentations. However, on the level of implementation, this success is difficult to measure. Although the project was fully constructed within a very limited budget and timescale, still the usage of the space was not fully achieved as planned, since changing the culture of using ISs as spaces that do not belong to anyone and can be used for informal parking or garbage collection to places that offer common and shared usage to all locals needs more time and public participation.

\section{Conclusions}

To conclude, the project presents a model for youth participation in shaping their city and being proactive citizens who share their creative vision with the local authority. For Tripoli in general and El Mina city in particular, the main stakeholders of the city should meet together often, hear about their mutual needs and share the decision-making. This exercise should be repeated in similar projects in different places. The stakeholders are the youth, local residents including local children, local authorities representing the municipality, cultural centre, and 
educational facility. This sharing could be the start of a legalization process involving adding the youth and children's needs to the urban code of the city. The project also highlights the need to take advantage of the ISs that can be used in a creative method to fulfil the needs of the youth or children that are currently missing from the urban form of an old city.

\section{Acknowledgements}

The project was funded by the SouthMed CV Foundation and co-funded by the European Union with the framework of the regional programme Med-Culture, project code: 02-01053. Thanks to the main applicant El Safadi Cultural Center - Centre Culturel El Sfadi: Mrs. Samira Baghdadi, Mohamed Alam Eldin and El Mina municipality, especially Dr. Amer Fidalla and the entire team. In addition, thanks to our BAU team: Arch. Sara Maassarani, Arch. Fatima Belok, BAU staff and students.

\section{References}

Barrow, L., \& Mathew, A. (2005). Digital design and manufacturing - a new era of representation. Retrieved from http://larrybarrow.com/assets/publications/15.pdf

Bosworth, C. E. (Ed.). (2007). Historic cities of the Islamic World. Leiden, Boston: Brill. https://doi.org/10.1163/ej.9789004153882.i-616

Chan, L., Erlings, E., Mizunoya, S., \& Zaw, H. (2016). A city fit for children: mapping and analysis of child friendly cities initiatives. The Chinese University of Hong Kong, Centre for Rights and Justice Occasional, Paper Series 5. Retrieved from https://www.law.cuhk.edu.hk/en/research/crj/download/ papers/Child_Friendly_Cities.pdf

Derr, V., Chawla, L., Mintzer, M., Flanders Cushing, D., \& Vliet, Van W. (2013). A City for all citizens: integrating children and youth from marginalized populations into city planning. Buildings, 3, 482505. https://doi.org/10.3390/buildings3030482

Francis, M., \& Lorenzo, R. (2002). Seven realms of children's participation. Journal of Environmental Psychology, 22(1-2), 157-169. https://doi.org/10.1006/jevp.2001.0248

Gulick, J. (1963). Images of an Arab City. Journal of the American Institute of Planners, 29(3), 179-198. https://doi.org/10.1080/01944366308978063

Hart, R. A. (1992). Children's participation: From Tokenism to Citizenship. Innocenti Essays, 4. Florence: UNICEF International Child Development Centre.

International Child Friendly Cities Secretariat. (2018). Building blocks for developing a child friendly city. Retrieved from https://www.unicef.or.jp/cfc/about/pdf/CFC_Building_Blocks.pdf

Lau, D. (2012). Interstitial urbanism: inhabiting the "in-between" (Master Thesis). Carleton University, Ottawa, Ontario (unpublished source).

Lefebvre, H. (1991). The production of space. Oxford: Blackwell Publishers Ltd.

Hassan M. Nour, El O. (2013). Building child friendly cities in the MENA region. International Review of Education, 59(4), 489-504. https://doi.org/10.1007/s11159-013-9373-1

Malone, K. (2013). Kazakhstan child friendly cities: Final Report November, 2013. Sydney: University of Western Sydney, Centre for Educational Research.

Masri, S. S. (2018). Integrating youth in city planning: developing a participatory tool toward a childfriendly vision of Eastern Wastani - Saida. Alexandria Engineering Journal, 57(2), 897-909.

https://doi.org/10.1016/j.aej.2017.01.023 
Mohareb, N., \& Maassarani, S. (2018). Design-build: an effective approach for architecture studio education. ArchNet International Journal of Architectural Research, 12(2), 146-161.

https://doi.org/10.26687/archnet-ijar.v12i2.1570

Shaw, P., \& Hudson, J. (2009, 2-4 July). The qualities of informal space: (re)appropriation within the informal, interstitial spaces of the city. Proceedings of the Conference "Occupation Negatiations of the Constructed Space” (pp. 1-13). University of Brighton, Brighton, Eastbourne, Hastings, England.

Stein, J. (2014). KidsRights Report. Child participation: from rights to reality. Retrieved from https://kidsrights.org/sites/default/files/inline-files/KidsRights\%20Report\%20-\%20Child\%20Participation\%20 v2016.pdf

Un-Habitat. (2016). Tripoli city profile. Retrieved from https://reliefweb.int/sites/reliefweb.int/files/resources/2016.10.28_UN-HABITAT_TripoliCityProfile_SpreadsMR.pdf

UNICEF National Comittees and Country Offices. (2009). Fact. Retrieved from https://www.unicef.de/ blob/23350/110a3c40ae4874fd9cc452653821ff58/fact-sheet--child-friendly-cities--data.pdf

\title{
VAIKAMS PALANKUS MIESTAS: JAUNIMO KŪRYBINE் VIZIJA EL MINOS (TRIPOLIS, LIBANAS) TARPINIŲ ERDVIŲ PERTVARKYMO KLAUSIMU
}

\author{
Nabil MOHAREB, Eslam ELSAMAHY, Mary FELIX
}

\section{Santrauka}

Nors senieji Arabijos miestai buvo suprojektuoti principu „iš apačios į viršų“ siekiant patenkinti jų vartotojų poreikius, tačiau ị viešąsias erdves, skirtas naudotis vaikams, nebuvo iki galo atsižvelgta. Šis straipsnis - tai rezultatas finansuoto projekto, kuriame dalyvavo 30 jaunuolių (13-17 metų amžiaus) iš skirtingų El Minos miesto, įsikūrusio Šiaurès Libane (Tripolyje), dalių. Projekto tikslas nebuvo varžomas kuriamų gebejjimų ar projektuojamos struktūros kaip vien tik vaikams palankaus miesto vizijos, skirtos jaunimui; projektu taip pat buvo pademonstruotas bendruomenès dalyvavimas, ịsitraukiant jaunimui, siekiant ịgyvendinti dizaino idèjas nenaudojamoje tarpinejje erdvejje senoviniame El Minos mieste. Finansuotą projektą sudarẻ daug skirtingų etapų; šiame straipsnyje susitelkiama ị vietos parinkimą, projektavimo procesą ir galutini igyvendinimo etapą. Gauti rezultatai iliustruoja jaunimo dalyvavimo suteiktas pamokas, adaptyvų pakartotinį tarpinių erdvių naudojimą, be to, ìvairius projekto suinteresuotų šalių interesus.

Reikšminiai žodžiai: vaikams palankus miestas, kūrybinis mokymasis, El Mina (Tripolis), tarpinès erdvès, jaunimo dalyvavimas, jaunimo vizija. 